\title{
NATURAL VENTILATION PERFORMANCE OF FAMILY BUILDING IN COLD CLIMATE DURING WINDLESS TIME
}

\author{
Romana ANTCZAK-JARZĄBSKA ${ }^{1}$, Maciej NIEDOSTATKIEWICZ ${ }^{1}$ \\ ${ }^{1}$ Gdańsk University of Technology, Faculty of Civil and Environmental Engineering \\ 80-233 Gdańsk, Narutowicza 11/12, Poland \\ romana.antczak@pg.edu.pl; maciej.niedostatkiewicz@pg.edu.pl
}

\begin{abstract}
In this paper, the field measurements results are presented on the stack ventilation effect. The paper presents the results of performance (air change rate $\mathrm{ACH}$ ) natural ventilation for building with inlet gap measured for the transitional season (between heating and summer season). The measurements were performed during a windless time. The house was located in northern Poland, in a cold climate region. The measurement system measured local climate conditions, indoor climate conditions and air velocities in vent inlet and outlet. In this paper, the discharge coefficient was checked. The discharge coefficient of 0.83 was higher than the discharge coefficient of 0.6 which was usually assumed for small rectangular openings during the natural ventilation. In a wind absence when the stack effect acted only, the air change rate (ACH) slightly exceeded the standard minimum value.
\end{abstract}

Keywords: natural ventilation, $\mathrm{ACH}$, discharge coefficient

\author{
WYDAJNOŚĆ WENTYLACJI NATURALNEJ PODCZAS DNI BEZWIETRZNCYH \\ W BUDYNKACH MIESZKALNYCH ZLOKALIZOWANYCH W KLIMACIE CHŁODNYM
}

Streszczenie

W artykule przedstawiono wyniki z pomiarów, podczas których zauważalny był efekt kominowy. W pracy przedstawiono wyniki działania (szybkość wymiany powietrza $\mathrm{ACH}$ ) wentylacji naturalnej w budynku, z nawiewnikiem okiennym. Badania prowadzone były w sezonie przejściowym (między sezonem grzewczym a letnim). Pomiary przeprowadzono podczas okresu bezwietrznego. Testowe mieszkanie zlokalizowane jest $\mathrm{w}$ północnej części Polski w klimacie chłodnym. System pomiarowy mierzył lokalne warunki klimatyczne w pomieszczeniach i prędkości powietrza zarówno na wlocie i wylocie z kanałów wentylacyjnych. W artykule sprawdzono współczynnik rozładowania. Współczynnik rozładowania wskazywał wartość 0.83 i był wyższy od zwykle przyjmowanego, który wynosi 0.6 dla tego typu układu (mały prostokątny nawiewnik). Wyniki badań pokazały, że w przypadku braku wiatru, gdy działał tylko efekt wyporu, szybkość wymiany powietrza $(\mathrm{ACH})$ nieznacznie przekraczała wartości określone jako minimalne.

Słowa kluczowe: wentylacja naturalna, $\mathrm{ACH}$, współczynnik rozładowania.

\section{INTRODUCTION}

The economic realities in Poland and building construction common practices over the years favor the cheapest ventilation systems which are natural ventilation. Natural ventilation is driven by two physical phenomena, wind and buoyancy (stack effect) caused by the temperature difference between indoor and outdoor air temperatures [1]. Natural ventilation should works when all natural forces are available or one of them. Unfortunately one of the most disadvantages of natural ventilation is reduced control of air distribution within the building, and lack of effectiveness during summer conditions with minimal wind. In the article we use three essential aspects of natural ventilation to describe and classify various concepts. The first aspect is the natural force utilized to drive the ventilation. The driving force can be wind, buoyancy or a combination of both. The second aspect is the ventilation principle used to exploit the natural driving forces to ventilate a space. This can be done by single-sided ventilation, cross ventilation, or stack ventilation (Fig.1) [2]. The third aspect is the characteristic ventilation element used to realize natural ventilation. The most important characteristic elements are wind towers, wind scoops, chimneys, double facades, atria and embedded ducts. 


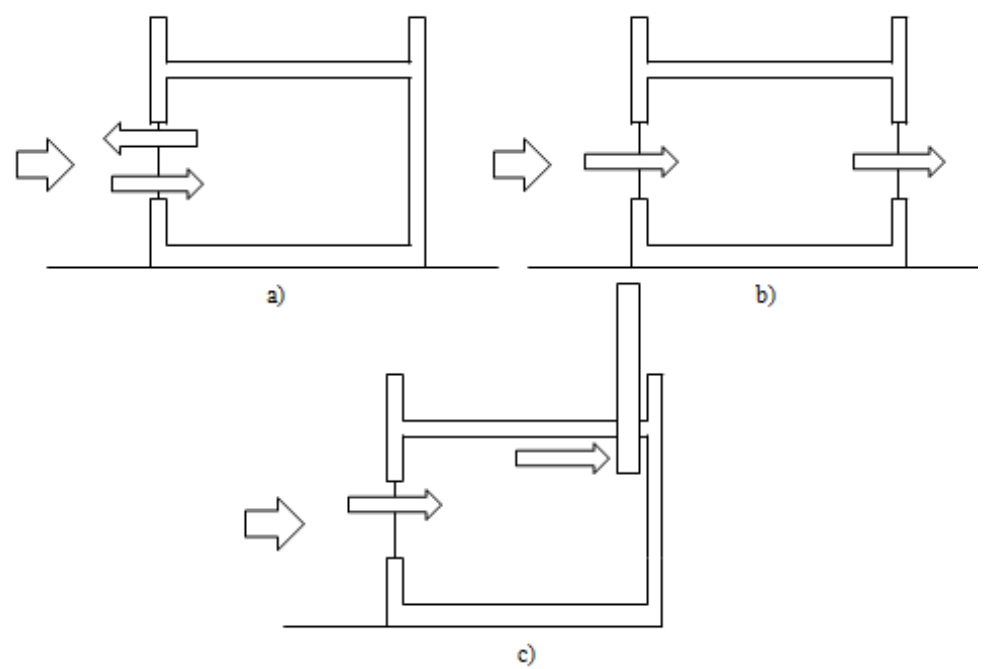

Fig. 1. Type of natural ventilation in building: a) single-sided ventilation, b) cross ventilation, c) stack ventilation.

In Central and Eastern European countries and special in Poland still the most common ventilation type is the natural ventilation with emphasis on stack ventilation. The air inflow in such system is provided through open windows, window cracks or air inlet grills. Indoor air outlet vents are usually located in bathrooms and kitchens. Almost all year in Central Europe indoor temperatures are higher than the outdoor temperature what induces a correct airflow pattern, i.e. from windows to chimneys. The stack ventilation in a configuration with inlet gap and chimney is very difficult for controlling the air quality and thermal conditions. While unfavorable conditions, it may result even in the reverse airflow. Gładyszewska et al. [3] showed how highly affect have wind on airflow in building. They conclude that during the windy weather air can be remove more than three times more than in windless time. They proved that properly designed natural ventilation can be expected that it is capable of ensuring the appropriate air condition inside building during a winter. The large information about behavior of stack ventilation in building located in cold climate we get from Krzaczek et al. [4]. The Authors investigated stack ventilation effect for residential house with multi-chimneys configuration and a tilted window. They compared in detail mass balance and took into account changes of density. They conclude that the tilted window leeward wind reduced the overall stack ventilation effectiveness and performance (with respect to $\mathrm{ACH}$ ) below the standard requirement. Most designs for natural ventilation focus on the effect of wind. There is a particular lack of information about effect of buoyancy on ventilation with inlet gap and chimney. It is important to fully understand this type of natural ventilation under buoyancy effect in order to make its design more effective.

The quality of natural ventilation is usually determined by performance indicators of the ventilation system. Performance means air change rate $(\mathrm{ACH}) . \mathrm{ACH}$ it measures how quickly the air in

an interior space is replaced by air coming from outside. While the ventilation effectiveness is an indicator of the ability of a ventilation system remove the contaminant. Ventilation performance indicators are to provide the information concerning indoor air parameters in a room or a building. So, it is important proper information about realistic climate data of local climate conditions, but usually is not. Generally we have two different approaches: local climate condition (LCS) on the construction site and climate data in the Typical Meteorological Year (TMY). In the engineering practice, it is not common to take into account the local climate conditions. As we can see in study Jokisalo et al. [5] the most common practice is to use climate data from TMY. However Jokisalo et al. [5] rightly observed that based on climate data from TMY, values are usually slightly overestimated.

In this paper, performance (air change rate $\mathrm{ACH}$ ) of natural ventilation for building with inlet gap measured was performed. A typical residential detached house was chosen for the measurement campaign. The house was located in northern Poland, in a cold climate region. The field measurements were performed in a test apartment in family detached house. The measurement campaign started on 2nd of April 2014 at 18:00 o'clock and ended on 9th of April 2014 at 18:00 o'clock. In better knowledge behavior of the natural ventilation from experimental measurement the windless time was chosen. However, April is a month which the primary mechanisms for the transfer of air in building occur at the same time. The major contribution of the paper is the experimental determination of the natural (stack) ventilation in residential apartment with chimney configuration and a window with inlet gap on the air exchange rate. These results can be used to help design control strategies for simple natural ventilation schemes. 


\section{TEST HOUSE}

The test building is a two-story, two-apartment residential house located in Gdansk (northern Poland) in a cold climate region. The apartment with a floor area of approximately $50 \mathrm{~m}^{2}$ was selected for a measurement campaign. The apartment is located on the first floor and consists of a bathroom, bedroom, kitchen, living room and corridor. To simplify the ventilation system configuration, the bathroom, bedroom and corridor were excluded from the measurement space and isolated from the rest of the apartment. The indoor test space was limited to the living room and the kitchen. The test apartment was inhabited during the measurement campaign. The resident's activity was registered mainly in the morning and in the evening (after 5:00 pm). The same apartment was chose to study [6]. In the study [6] was present the performance of natural ventilation in cold climate during windy days.

The test apartment was equipped with the natural ventilation system in configuration with the air inlets and the chimneys ducts. The air inlets are small appliances mounted in the casement or window frame, which allow controlling fresh air inflow to the room. They were invented and introduced in 1960's in the Scandinavian countries [7]. In Poland, this type of the inlet gaps is obligatory in case of usage of stack ventilation in configuration with multi-chimneys ducts.

In this study, the test apartment was equipped with one air inlet gap located in the living room. According to the national regulations and standards $[8,9]$, the active flow area of fully open air-inlet should be designed to enable the airflow in the range from 20 to $50\left(\mathrm{~m}^{3} / \mathrm{h}\right)$ for pressure difference of $10 \mathrm{~Pa}$ on both sides of the opening. In the test apartment, the inlet gap was located just in living room and was being in a contact with the ambient air. When fully opened, it should ensure air exchange rate of 0.8 $[1 / \mathrm{h}]$. The chimney duct of $14 \times 14 \mathrm{~cm}^{2}$ (min. 0.016 $\mathrm{m}^{2}$ ) was located in the in the kitchen. The active area of the air inlet to the chimney duct was $0.008 \mathrm{~m}^{2}$. The air inlet into the chimney duct was equipped with controllable vent grill, which was located 0.15 $\mathrm{m}$ below the room ceiling.

The measurement system was limited to the two rooms (Fig.2) with usable area of $24.84 \mathrm{~m}^{2}$ and an air volume of $63.34 \mathrm{~m}^{3}$. The configuration with one air inlet (rectangular inlet gap in window frame) and one air outlet (chimney duct in kitchen) let reduce unknown parameters influencing the air exchange process. During the measurement time-period, all windows were closed. The doors inside the test apartment were closed during the night-time and during the resident's work-time.

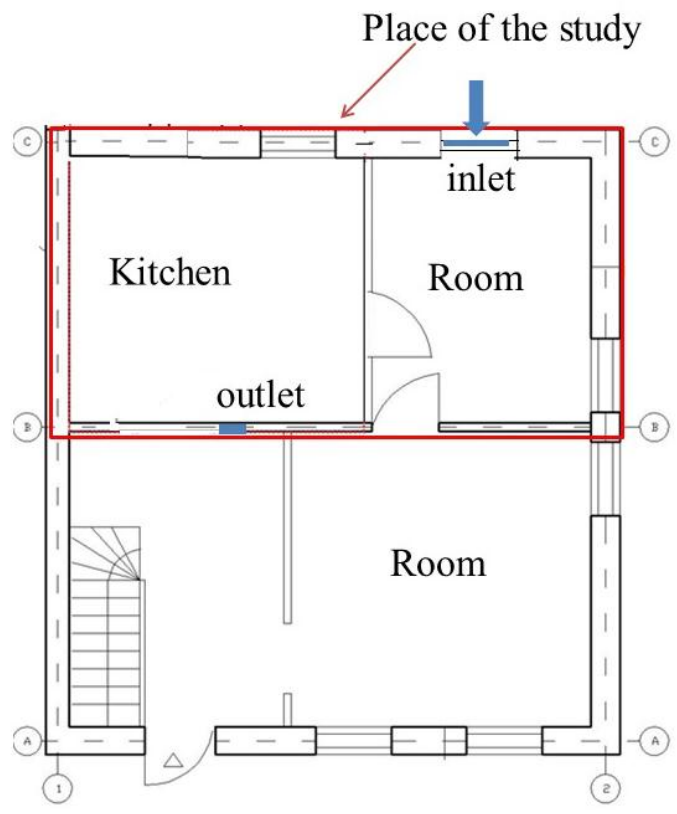

Fig. 2. The residential family detached test house sketch of the first floor.

The test house is a heavy-weight building. The floor slabs are made of concrete. The stone materials are used for both sides of the cavity walls. Building was built in the 1950s and thermally renovated in 2012. Table 1 provides the U-values overview of the main structural components.

\section{MEASUREMENT SETUP AND EQUIPMENT}

Under cold climate conditions of northern Poland, the ventilation works in a winter regime from November to March. January is the coldest month in Poland. The average temperature is about $4^{\circ} \mathrm{C}$ but it can fall as low as $-35^{\circ} \mathrm{C}$. While in the summer months of June, July and August, the temperature averages is about $18^{\circ} \mathrm{C}$ and the maximum summer temperature is $40^{\circ} \mathrm{C}$. All other time periods can be called the Transient Climate Conditions (TCC). In the article TCC are characterized by a day temperature difference between the indoor and ambient temperature in the range of about $\left(20^{\circ} \mathrm{C},-2^{\circ} \mathrm{C}\right)$. They are the most

Table 1. Overview of construction details for the base case building from 2012

\begin{tabular}{|l|l|c|}
\hline \multicolumn{1}{|c|}{ Element } & \multicolumn{1}{|c|}{ Details } & \multicolumn{1}{|c|}{ U-value } \\
\hline External wall & $\begin{array}{l}\text { Cavity wall with (inside to outside): limestone inner } \\
\text { layer, thermal insulation, brick outer layer }\end{array}$ & $0.18 \mathrm{~W} /\left(\mathrm{m}^{2} \mathrm{~K}\right)$ \\
\hline Internal wall & Limestone wall & - \\
\hline Door & Wood & $1.10 \mathrm{~W} /\left(\mathrm{m}^{2} \mathrm{~K}\right)$ \\
\hline Windows & Double panel glazing & $0.90 \mathrm{~W} /\left(\mathrm{m}^{2} \mathrm{~K}\right)$ \\
\hline
\end{tabular}


unfavorable conditions during the entire year. This is because the stack effect is reduced significantly, while the impact of wind gusts is very random and dependent upon a ventilation configuration. However, the time period of transient climate conditions is very advantageous for field investigations of a quality of natural ventilation.

The measurement system was designed for the constant monitoring of indoor climate conditions, ambient climate conditions and airflow velocity in vent inlets and outlets. It included sensors, port data acquisition modules, network switch and PC computer (Fig.3). All sensors were wire-connected directly to the data acquisition modules which registered the measured data and were connected to the PC computer via the 16-port Ethernet Switch. The measurement data management software LBX 2012 of LAB-EL [10] was installed in the PC computer. Data collected in the module data acquisition were automatically transferred to the SQL database, located on a PC computer. The sensors and the data acquisition modules worked in a real-time mode while the data management software was synchronized with the data acquisition module at each probe time step.

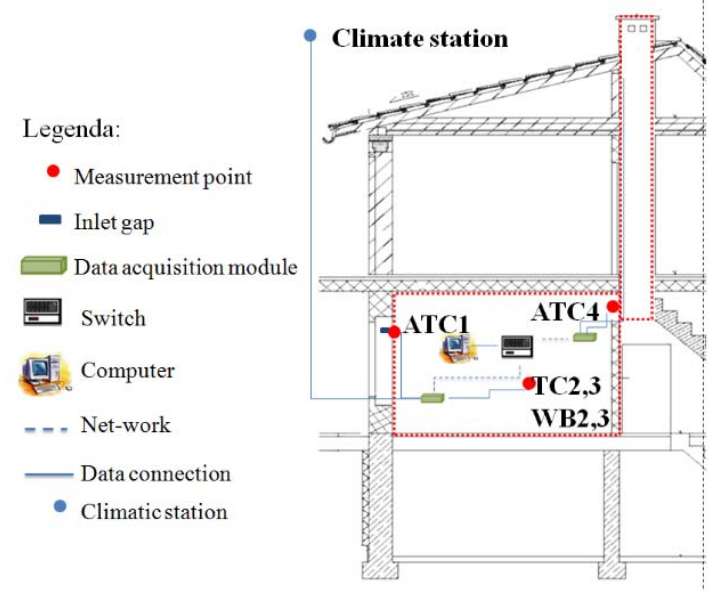

Fig. 3. The measurement system in the test house.

The test apartment was divided by lightweight internal walls into the rooms. The door between the rooms was open. The air velocity and temperature were registered in the vent inlet (A1 and T1) and outlet (A4 and T4). In the indoor zone, the indoor climate conditions were monitored and measured. The air temperature was measured in 2 points of the test apartment: (T2) in living room and (T3) in kitchen and the air relative humidity was measured in the same 2 points as the temperature: (W2) in living room and (W3) in kitchen. The barometric pressure was registered in 1 point in the leaving room (B2). All sensors were located in the rooms at the height $1.6 \mathrm{~m}$ from the floor level. Ventilation performance indicators are to provide the information concerning indoor air parameters in a room or a building. So, it is important proper information about realistic climate data of local climate conditions. In that case the local climate station was built. The climate station measured the wind velocity $[\mathrm{m} / \mathrm{s}]$, wind direction $\left[{ }^{\circ}\right]$, pressure $[\mathrm{Pa}]$, relative humidity [\%] and temperature of the ambient air $\left[{ }^{\circ} \mathrm{C}\right]$ and solar radiation $\left[\mathrm{W} / \mathrm{m}^{2}\right]$.

To perform measurements were used components of the LAB-EL products line [10]. In the climate station, there was the omnidirectional wind anemometer LB-747 with the measurement range of $0.5 \mathrm{~m} / \mathrm{s}$ to $90 \mathrm{~m} / \mathrm{s}$ and accuracy of $2 \%$. The omnidirectional wind anemometer LB-747 of the climate station was located on the building roof at the height of $9.69 \mathrm{~m}$ above the ground level and 2.05 $\mathrm{m}$ above the roof ridge. The barometric pressure was measured with LB-716, which worked in the absolute pressure mode within the range of 2-200 $\mathrm{kPa}$ and accuracy of $\pm 0.5 \mathrm{kPa}$. The temperature and relative humidity were measured with the thermohygrometer LB-710R. Its temperature range was $40-85^{\circ} \mathrm{C}$ with the accuracy of $\pm 0.1^{\circ} \mathrm{C}$ and its relative humidity range was $99 \%$ with the accuracy $\pm 2.0 \%$. In the indoor zones the barometric pressure was measured with LB-750 which worked in the absolute pressure mode within the range $0.1-120 \mathrm{kPa}$ and accuracy of $\pm 0.1 \mathrm{kPa}$. The air velocity and temperature were registered in the vent inlet and outlet. Due to a complex airflow characteristics in vent inlet (long rectangular shape) and potential flow direction changes, the air velocity measurement was difficult. In this measurement campaign, the thermoanemometers LB-801A and LB-801C were installed in a double-sensor configuration. The both thermoanemometers were based on a hot-wire concept. The first thermo-anemometer LB-801A worked in an analog mode and measured the low velocity. The sensor was capable to the measure indoor convection air velocity between $0.05-10 \mathrm{~m} / \mathrm{s}$ with the accuracy of $\pm 0.05 \mathrm{~m} / \mathrm{s}$. The second thermo-anemometer LB$801 \mathrm{C}$ worked in a digital mode and was used to detect the airflow direction. The airflow direction detection function was designed by a modification of the LB-801C sensor. The sensor was modified by closing its airflow channel from one side and recalibrating its characteristics for two opposite flow directions. The new characteristics were written into its EPROM memory. The both sensors were installed as an integrated measurement point. The measurement data management software LBX 2012 registered the flow direction and air velocity. All sensors were calibrated by the LAB-EL Laboratory in Poland before installation and commissioning. The sensors were confirmed by suitable calibration certificates.

\section{DISCHARGE COEFFICIENT}

Computation of natural ventilation air flow through windows, doors and cracks are most commonly made using discharge coefficients. Many of the discharge coefficient values used are derived from data traditionally used for fluid flow by openings. A discharge coefficient value of 0.6 for a sharp-edged rectangular opening is often used for 
openings (Dascalaki et al. 1999) [11]. The value is regarded as constant. In the article a discharge coefficient value for small rectangular opening was tested. The discharge coefficient was investigated during a steady climate conditions in the wind absence (wind velocity $0 \mathrm{~m} / \mathrm{s}$ ). In the wind absence when the stack effect solely acts, the airflow rate $q_{s t}$ can be derived analytically for the single-sided ventilation (Brown et al. 1962) [12]:

$$
q_{s t}=1 / 3 A_{\text {eff_out }} C_{d} \sqrt{\Delta T H g / T_{a v}}
$$

Where $C_{d}$ is the discharge coefficient, $\Delta T$ denotes the air temperature difference between indoor and ambient conditions, $H$ stands for the opening height, $g$ is gravity acceleration and $T_{a v}$ denoted the average air temperature between the indoor and ambient conditions. The number means that only of the effective flow area takes part in supplying the fresh air and of the effective flow area removes the waste air.

To analyze the stack effect, the time period of no wind and a positive temperature difference between the indoor air and ambient air was chosen. The unsteady nature of the air exchange process in the test apartment and a complex ventilation configuration make the stack effect to define as the ability of the ventilation system to release the waste indoor air owing to the temperature driven forces. The stack effect can be estimated directly as the total volumetric air flow rate in the air outlet in the wind absence:

$$
\dot{V}_{s t}=\bar{V}_{\text {inlet }}+\bar{V}_{\text {leak }}
$$

where $\bar{V}_{\text {inlet }}$ the time-averaged volumetric air flow rate in inlet gap in ATC1 and positive $\bar{V}_{\text {leak }}$.

Finally the loss coefficient for the wind absence can be determined from:

$$
C_{d}=\dot{V}_{s t} / q_{s t}
$$

The mean theoretical stack effect was $0.018 \mathrm{~m}^{3} / \mathrm{s}$ (Fig.4) with SD of 0.0023 which agree well with the mean measured stack effect $\dot{V}_{s t}=0.015 \mathrm{~m}^{3} / \mathrm{s}$ with SD of 0.0020 . While, the mean discharge coefficient $C d$ was 0.83 with SD of 0.047 . The discharge coefficient of 0.83 is higher than the discharge coefficient of 0.6 , usually assumed for small rectangular openings during the natural ventilation. It is in agreement with the research results of Tan and Glicksman in 2005 [14].

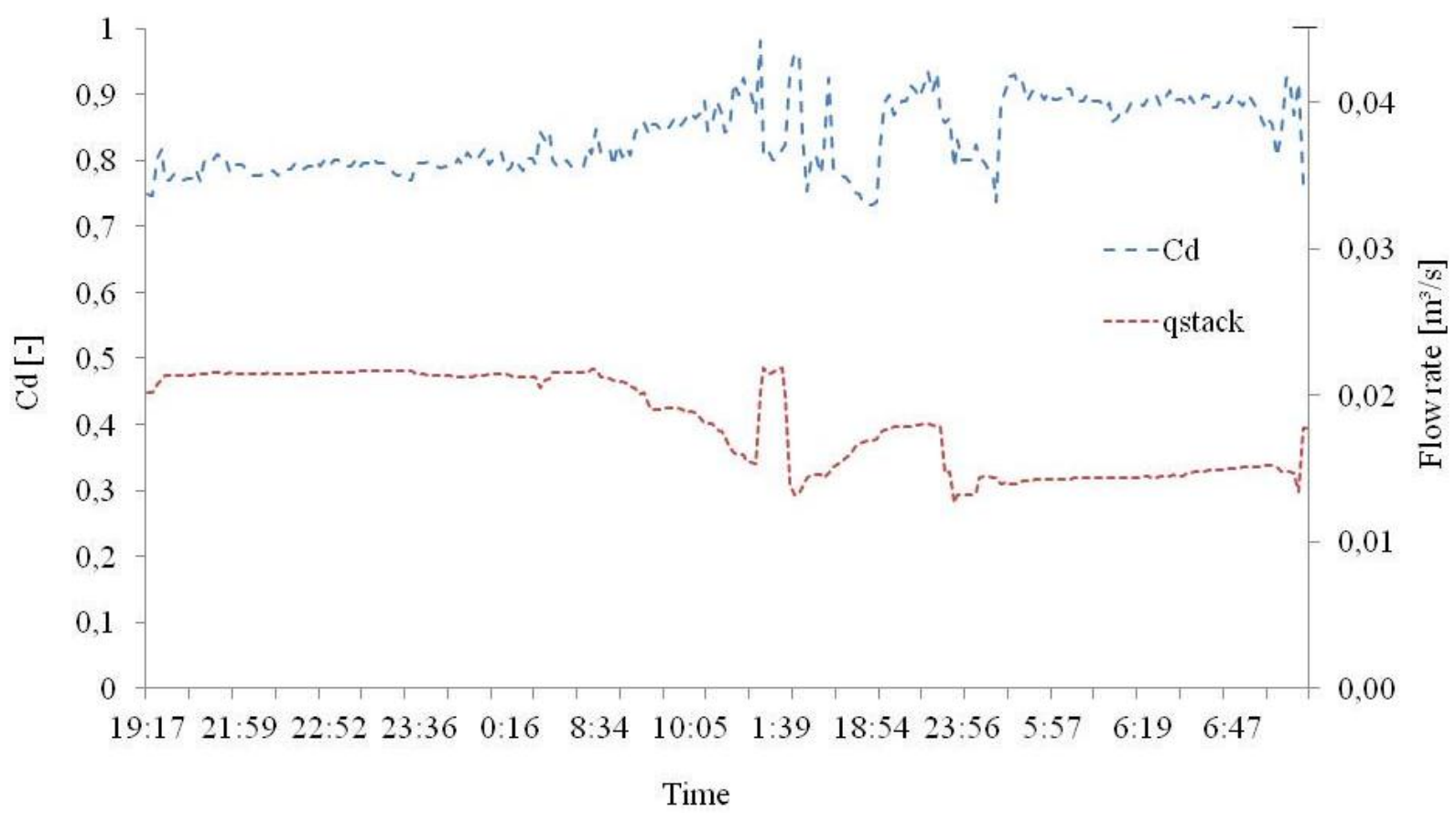

Fig. 4. Comparison of stack effect with loss coefficient $C d$

\section{VENTILATION PERFORMANCE}

The quality of natural ventilation indices used in this study is performance indicators. Performance means air change rate $(\mathrm{ACH})$ and it is a measure of how many times the air within a defined space is replaced. The air change rate per hour $(\mathrm{ACH})$ is calculated based on the ratio of air supply ( $\left.A_{\text {eff inlet }} U_{\text {inlet }}\right)$ into a zone (i.e. a room or space) in relation to the volume of this zone room volume $\left(\mathrm{V}_{\mathrm{R}}\right)$ [13]. The air supply $\left(A_{\text {eff } f \text { inlet }} U_{\text {inlet }}\right)$ will be named $\dot{V}(t)$. It is generally expressed as air change per hour $\left[\mathrm{h}^{-1}\right]$ or $[\mathrm{ACH}]$. The $\mathrm{ACH}$ is defined by ASHRAE as: 
Where:

$$
A C H(t)=\frac{\dot{V}(t) * 3600}{V_{R}}
$$

$\mathrm{ACH}(\mathrm{t})$-is the ventilation rate or air change rate, $\mathrm{h}^{-1}$

$\dot{V}(\mathrm{t}) \quad$-is the total air supply into a room, $\mathrm{m}^{3} / \mathrm{h}$

$\mathrm{V}_{\mathrm{R}} \quad-\mathrm{s}$ the room's volume, $\mathrm{m}^{3}$

\section{DISCUSSION}

A typical residential building with available measurements of climatic conditions, indoor airflow and temperature was chosen as a case study. During measurements test apartment was occupied by two adults in different time (special after 5:00 o'clock). The results discussion includes performance with respect to the air change rate $(\mathrm{ACH})$ for different time. The measured parameters included wind velocity and direction, outdoor air dry-bulb temperature, indoor air temperatures, air speed at the window crack.

\subsection{Climate condition}

In this case, study based on real climate conditions. The measurement campaign held in the month of April. Fig.5 shows driving forces in natural ventilation measured on the construction site. The most unpredictable conditions during the entire year for natural ventilation caused wind effect. We already know how strong impact has wind on the air change rate in building [15]. Besides we know that the stack effect is reduced significantly, while the impact of wind gusts is significant. So, in that case wind effect could not be ignored. However, the major contribution of the paper is the experimental determination of the stack effect on the air exchange rate for natural ventilation with inlet gap.

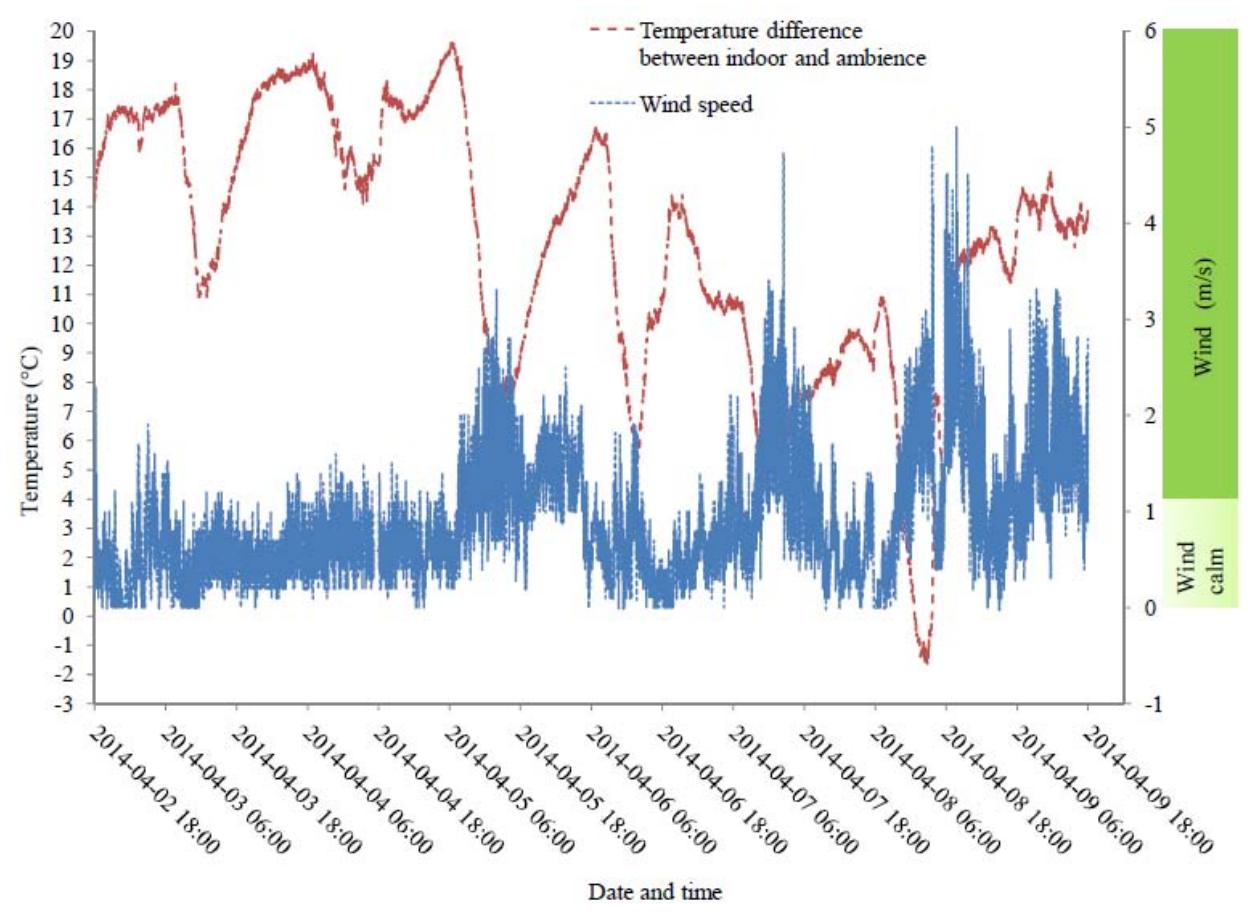

Fig. 5. Driving forces in natural ventilation measured on the construction site

During the experiment temperature difference between the indoor and ambience was in the range of about $\left(20^{\circ} \mathrm{C},-2^{\circ} \mathrm{C}\right)$. Wide temperature variation gives us an idea of the impact of buoyancy on ventilation with inlet gap and chimney. In that case no-wind time was separated to enable to study the stack effect on air change rate.

\subsection{Ventilation performance}

In better knowledge the influence of Windless time on $\mathrm{ACH}$ in building, this study was prepared. The ventilation performance was investigated as the air change rate per the apartment total volume during $1 \mathrm{~h}(\mathrm{ACH})$. The results were compared with the requirements of the industry standard [7] (the natural ventilation in the test apartment should exchange $50 \mathrm{~m}^{3} / \mathrm{h}$ during the day-time and $30 \mathrm{~m}^{3} / \mathrm{h}$ during the night-time). Figure 6 shows a large timevariation of $\mathrm{ACH}$ during the windless time. Consider this time-variation the air change rate in experiment was varied between a minimum of $\mathrm{ACH} \approx 0,08 \mathrm{~h}^{-1}$ $\left(\mathrm{V} \approx 5,1 \mathrm{~m}^{3} / \mathrm{h}\right)$ and a maximum of $\mathrm{ACH} \approx 1,28 \mathrm{~h}^{-1}(\mathrm{~V}$ $\approx 80,08 \mathrm{~m}^{3} / \mathrm{h}$ ). The mean measured air change rate for buoyancy ventilation was 0,75 with the significant standard deviation (SD) of 0,74 . For windless time the night-

time flow rate was fulfilled on $82 \%$ of that time while the day-time flow rate was fulfilled on $68 \%$ of that time. The highest value of $1,28 \quad 1 / \mathrm{h}$ was observed during the morning (8:00 o'clock) while the lowest of $0.08 \mathrm{1} / \mathrm{h}$ during the midday (12:00 o'clock). 


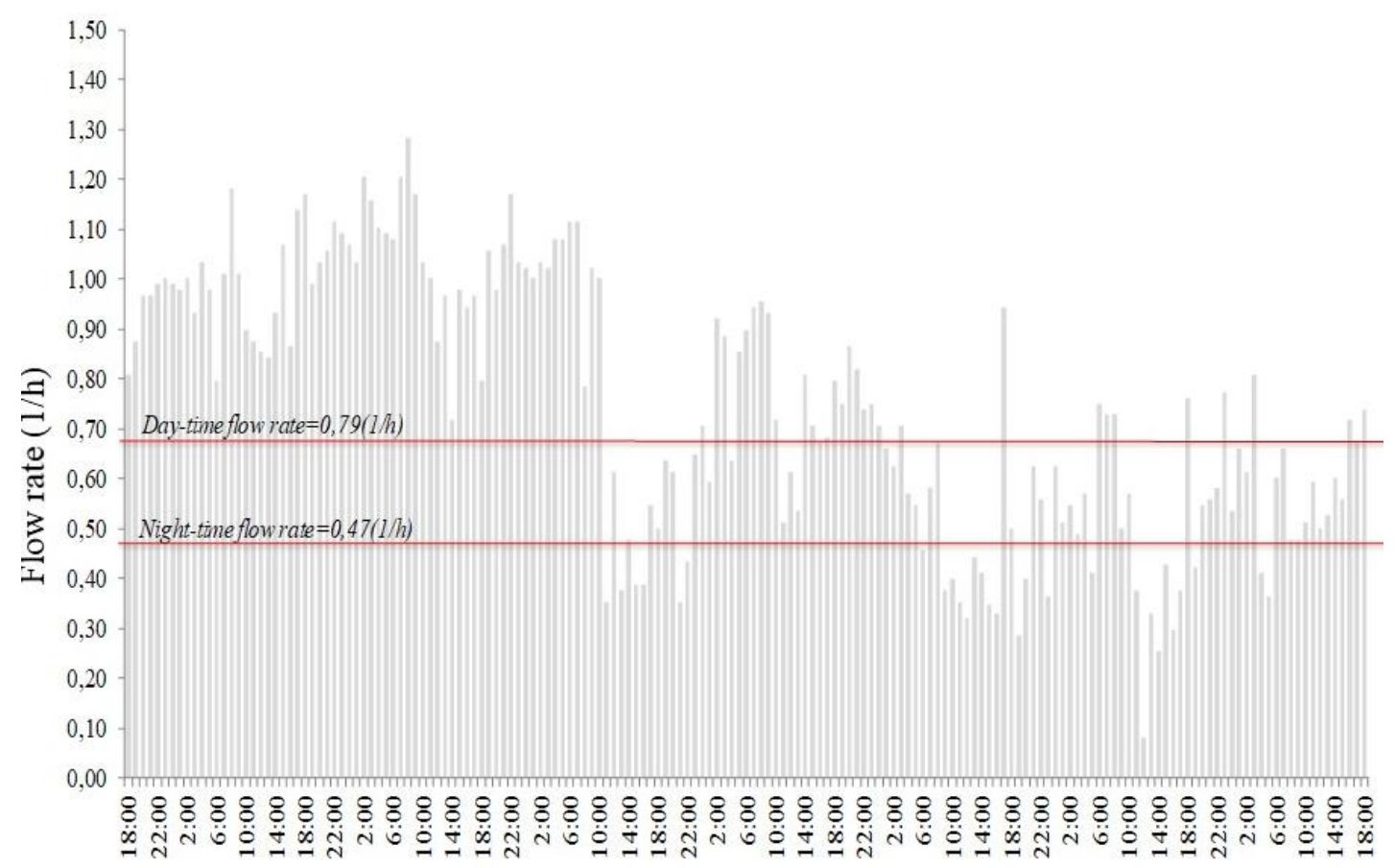

Time

Fig. 6. Measured flow rate for the test apartment during the windless time.

The ventilation performance with temperatures differences between indoor and ambience effect on the flow rate in the apartment was shown in fig. 7. The temperature difference shows clearly relation. It was observed, when the temperature difference was bigger than the $\mathrm{ACH}$ increases, when the temperature difference decreases the $\mathrm{ACH}$ significantly decreases. The natural ventilation performance for the highest temperature difference
$19,3{ }^{\circ} \mathrm{C}$ was $1,111 / \mathrm{h}$. During the lowest temperature difference $1{ }^{\circ} \mathrm{C}$ air change rate $(\mathrm{ACH})$ was $0,08 \mathrm{l} / \mathrm{h}$. In the study was observed, that the highest value of $\mathrm{ACH} 1,281 / \mathrm{h}$ was for the temperature difference $18,3{ }^{\circ} \mathrm{C}$. It is means that on the $\mathrm{ACH}$ increasing had influence not only temperature. During the study was time when the ambience temperature was higher than indoor temperature. This moment was observed for windless time (wind velocity was in the range $0 \div 3 \mathrm{~m} / \mathrm{s}$ ).

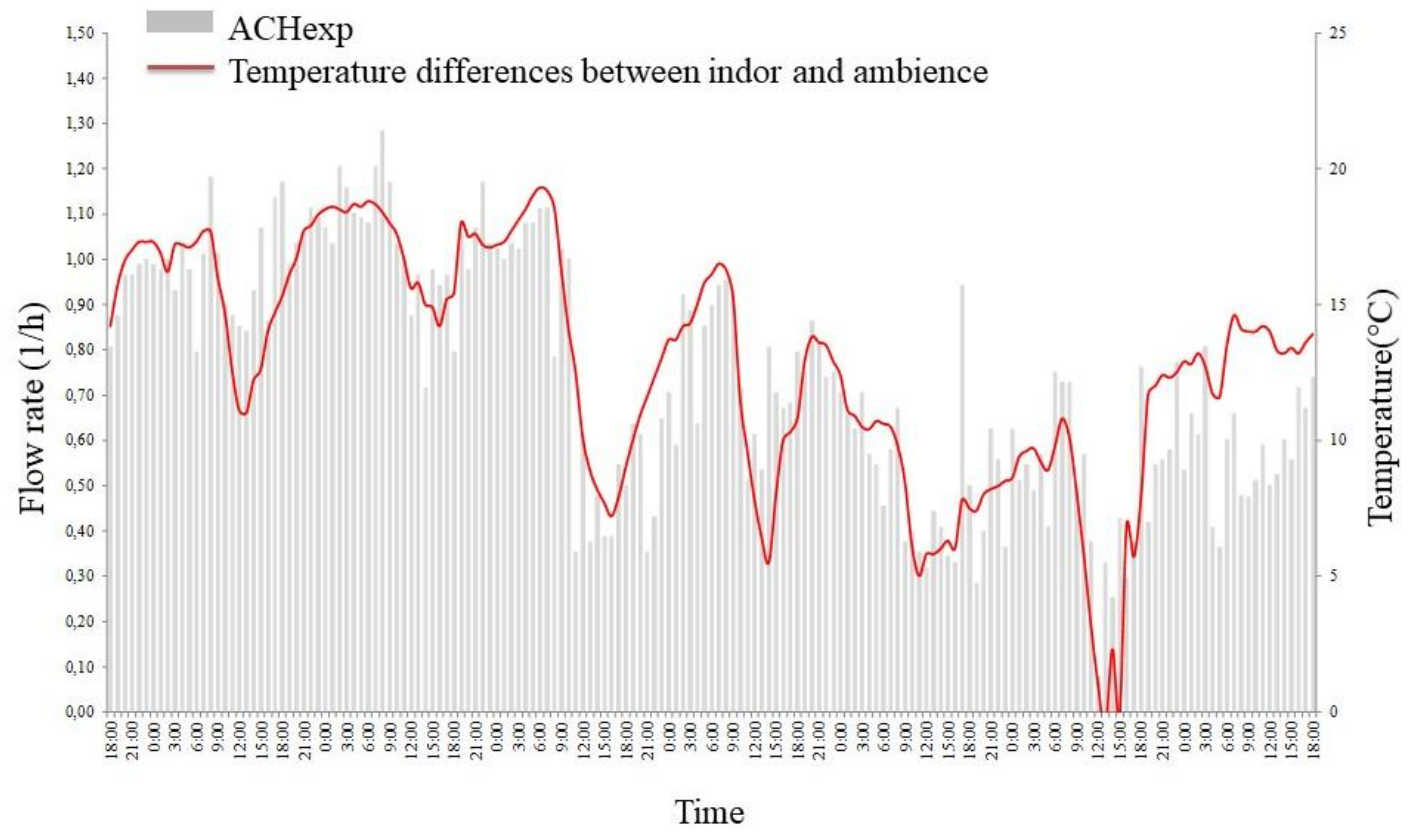

Fig. 7. Measured flow rate and related temperatures differences between indoor and ambience for the test apartment during the windless time 


\section{CONCLUSIONS}

The field investigations of prediction of air flow rate in the apartment with natural (stack) ventilation with inlet gap in window were performed. The measurements were carried out in a test apartment of a family detached house located in a cold climate. The measurement campaign was performed under transient climate conditions:

1. The experimental results confirmed the assumption about discharge coefficient. The discharge coefficient of 0.83 was higher than the discharge coefficient of 0.6 which was usually assumed for small rectangular openings during the natural ventilation.

2. The air change rate was investigated under steady climate conditions for windless time. During the height temperatures differences between indoor and ambience even was $14{ }^{\circ} \mathrm{C}$, the natural ventilation performance can be weakened by temporary radiation. However, when the wind was absent the minimum night requirement was fulfilled for temperature differences minimum of $8{ }^{\circ} \mathrm{C}$ and for the day the minimum was $14^{\circ} \mathrm{C}$.

3. The worst ventilation performance was investigated for air change rate value lower then $0,1 \mathrm{1} / \mathrm{h}$. It was noticed when the wind was absent and the temperature difference was just $1{ }^{\circ} \mathrm{C}$.

\section{REFERENCES}

1. LBNL, 2007, EnergyPlus Engineering Reference, November 6, 2007 p384 and p381.

2. Kleiven T. Natural Ventilation in Buildings. Architectural concepts, consequences and possibilities, Norwegian University of Science and Technology, 2003.

3. Gładyszewska-Fiedoruk K, Gajewski A. Effect of wind on stack ventilation performance. Energy and Buildings 2012; 51: 242-247. https://doi.org/10.1016/j.enbuild.2012.05.007.

4. Krzaczek M, Florczuk J, Tejchman J. Field investigations of stack ventilation in a residential building with multiple chimneys and tilted window in cold climate, Energy and Buildings, 2015: 103: 48-61, https://doi.org/10.1016/j.enbuild.2015.06.034.

5. Okisalo J, Kurnitski J, Korpi M, Kalamees T, Vinha J. Building leakage, infiltration, and energy performance analyses for Finnish detached houses. Building and Environment 2009; 44:377-387.

6. Jarząbska-Antczak R, Niedostatkiewicz M. Natural ventilation performance of family building in cold climate during windy days. DIAGNOSTYKA, 2018, 19(1):. 103-116. https://doi.org/10.29354/diag/82977

7. Bülow-Hübe H. Energy-Efficient Window Systems. Doctoral Dissertation. Lund University, Lund Institute of Technology, Lund 2001.

8. PN-83/B-03430 (including revision A3:2000). Ventilation in collective dwelling places and public buildings - requirements, (in Polish).

9. Dutton S, Shao L and Riffat S. Validation and parametric analysis of energy plus: air flow. Network model using Contam. Third National Conference of IBPSA-USA. Berkeley, California. July 30 - August 1 , 2008.
10. LAB-EL Elektronika Laboratoryjna s.j. Available from www.label.pl.

11. Dascalaki E, Santamouris M, Bruant M, Balaras CA, Bossaer A, Ducarme D, Wouters P. Modeling large openings with COMIS, Energy and Buildings, 1999, 30: $105-115$.

12. Brown W.G., Solvason K.R., Natural convection through rectangular opening in partitions. 1. Vertical partitions. Heat and Mass Transfer 1962; 5: 859-868.

13. Axley J. Introduction to the design of natural ventilation system loopequation, Proc. 19th AIVC Conf. Ventilation Technologies Urban Areas, 47-56, 1998.

14. Tan G, Glicksman LR. Application of integrating multizone model with CFD simulation to natural ventilation prediction, Energy and Buildings, 2005, 37: 1049-1057

15. Awbi H. Ventilation of buildings, Chapman \& Hall, 1991.

Received 2018-02-07

Accepted 2018-05-10

Available online 2018-05-22

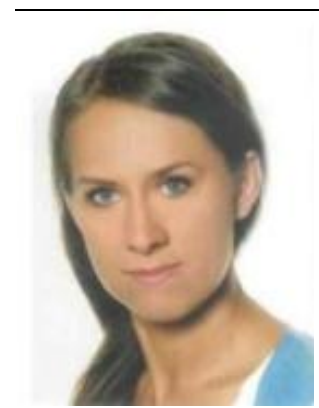

Romana ANTCZAK-

JARZĄBSKA, MSc Eng - is a graduate of the Gdańsk University of Technology, where she studied at the Faculty of Civil and Environmental Engineering, scientific fields of interests concern among building engineering physics, building's internal environment conditions and air ventilation.

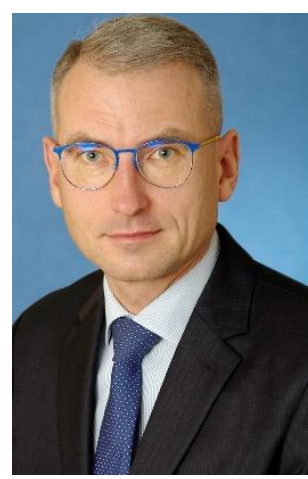

Maciej

NIEDOSTATKIEWICZ,

Ph.D., D.Sc. is an associate professor and Head of Department of Concrete Structures, Gdansk University of Technology. His scientific interests are related to the subject of diagnostics by means of non-invasive methods and reinforcement of structural elements of general construction and issues of building physics. 